\title{
Polymorphisms of Intron 1 and the Promoter Region at the PRNP Gene in BSE-Free Caracu Cattle
}

\author{
Cleber Eduardo Galvão • Grácia Maria Soares Rosinha • \\ Cristiane Camargo Sanches • Carina Elisei • \\ Flábio Ribeiro Araújo • Gelson Luís Dias Feijó • \\ Roberto Augusto de Almeida Torres Jr. • Cleber Oliveira Soares
}

Received: 23 May 2011/Accepted: 2 November 2011/Published online: 13 May 2012

(C) Springer Science+Business Media, LLC 2012

\begin{abstract}
The infectious prion protein $\mathrm{PrP}^{\mathrm{Sc}}$ is encoded by the PRNP gene. In cattle, insertion/deletion (indel) polymorphisms are among the changes that occur in this gene, the most studied of which are within intron 1 (12 bp) and the promoter region $(23 \mathrm{bp})$. Sequence variants in this gene may affect the formation of $\operatorname{PrP}^{\mathrm{Sc}}$. In the present study, nucleotide variability in specific regions of the PRNP gene in Caracu cattle free of bovine spongiform encephalopathy was investigated to determine the genotypic profile of each animal within the group. Caracu cattle exhibited high allele frequency for the two polymorphic regions studied, 12ins (70 \%) and 23ins (72.5\%), genotype frequencies of $50 \%$ for 12ins/ins and $50 \%$ for $23 \mathrm{ins} / \mathrm{del}$, and a high frequency of the 12ins-23ins haplotype $(57.5 \%)$. Of the 40 animals sampled, 15 had the 12ins-23ins/12ins-23ins diplotype.
\end{abstract}

Keywords Bovine spongiform encephalopathy $\cdot P R N P \cdot$ Prion · Indel $\cdot$ Caracu cattle

C. E. Galvão · C. C. Sanches

Universidade Federal de Mato Grosso do Sul, Programa de Pós-Graduação Mestrado em Ciência

Animal, Campo Grande, MS, Brazil

G. M. S. Rosinha · C. Elisei · C. O. Soares ( $₫)$

Embrapa Gado de Corte, Sanidade Animal, Laboratório de Engenharia Genética Animal,

Campo Grande, MS, Brazil

e-mail: cleber@cnpgc.embrapa.br

F. R. Araújo

Embrapa Gado de Corte, Sanidade Animal, Laboratório de Imunologia, Campo Grande, MS, Brazil

G. L. D. Feijó

Embrapa Gado de Corte, Manejo e Produção Animal, Campo Grande, MS, Brazil

R. A. de Almeida Torres Jr.

Embrapa Gado de Corte, Melhoramento Animal, Campo Grande, MS, Brazil 


\section{Introduction}

Bovine spongiform encephalopathy (BSE) belongs to the group of transmissible spongiform encephalopathies (TSEs). Diseases from this group affect various animal species, including humans (Czarnik et al. 2007). For many years, it was believed that these diseases were caused by a small virus known as scrapie (Prusiner and Scott 1997). The agent proposed for TSEs is a prion (proteinaceous infectious particle), or infectious protein, which may be denominated in its form as abnormal scrapie prion protein $\left(\mathrm{PrP}^{\mathrm{Sc}}\right)$ (Prusiner 1982). The normal prion protein, or cellular prion protein $\left(\mathrm{PrP}^{\mathrm{C}}\right)$, is a glycoprotein that is constantly produced and rapidly metabolized by nerve tissue (Moser et al. 1995). It is used as a receptor molecule as well as an adhesion molecule for neurons with neurotransmitter and antioxidant action, which in turn is linked to apoptosis.

$\mathrm{PrP}^{\mathrm{C}}$ is encoded by the PRNP gene located on bovine chromosome BTA13 at position q17 (Schläpfer et al. 2000). In cattle, insertion/deletion (indel) polymorphisms are among the changes that occur in the PRNP gene, as a sequence of $12 \mathrm{bp}$ in intron 1 and a sequence of $23 \mathrm{bp}$ in the promoter region. Sander et al. (2004) found that sequence variants in this gene may affect the amino acid sequence or the expression of prion protein and consequent susceptibility to BSE; the haplotype $12 \mathrm{del}-23 \mathrm{del}$ was more frequent in a group of cattle affected by BSE than in a group of healthy cattle from the same study. Assays with reporter genes demonstrated that indel polymorphisms are associated with expression levels of prion by the bovine PRNP gene (Sander et al. 2005; Kashkevich et al. 2007). Epidemiological surveys have shown that the occurrence of the classical form of BSE has no connection with the age or sex of the affected animal but, rather, is connected with the intake of animal protein contaminated with other mutated proteins, and there is no specific denaturing treatment (Wilesmith et al. 1988).

The Caracu cattle breed originates from crosses of the Iberian breeds Alentejana, Minhota, Mirandesa, Arouquesa, and Algaviriano. The first cattle breeds were introduced in Brazil by the Portuguese in 1534 in the state of São Paulo. After nearly five centuries of Caracu breeding in Brazil, the purebred animals have acquired a number of characteristics, such as resistance to certain parasitic diseases and adaptation to differing climates in Brazil, and thus exhibit good productive performance in various regions of the country. These are important factors for the raising and expansion of the Caracu breed in Brazil (Criar e Plantar 2008). The breed exhibits high fertility and longevity. Adult males can weigh as much as $1,100 \mathrm{~kg}$, and adult females $800 \mathrm{~kg}$. The Caracu is used for the production of both milk and meat (Kues et al. 2006). There are records of 80,000 animals of the breed in Brazil for the period between 1973 and 2009 (ABCC 2009).

The aims of the present study were to identify indel polymorphisms of the bovine PRNP gene at intron 1 (12-bp indel) and the promoter region (23-bp indel) in BSE-free Caracu cattle and to determine the genotypic profile of each animal sampled. 


\section{Materials and Methods}

\section{Sampling}

In this study, we genotyped 40 specimens of Caracu cattle, each from a different breeder in Brazil. The degree of consanguinity (or inbreeding coefficient, $F_{i}$ ) was 0-9 \%, and the degree of kinship was 0-7\%. Genetic material was extracted from blood and semen samples. Inbreeding and kinship coefficients were obtained using Matlab routines.

\section{DNA Extraction from Blood and Semen}

Genomic DNA was extracted from blood samples using the Easy-DNA kit (Invitrogen). Genomic DNA was extracted from semen samples using a method adapted from Zadworny and Kuhnlein (1990) and previously reported by Regitano and Coutinho (2001).

The purity of total DNA samples from blood and semen was checked using electrophoresis on $0.8 \%$ agarose gel (Promega) stained with SYBR Gold (Invitrogen). The gel was examined under an ultraviolet light transilluminator (Transiluminador, Loccus Biotecnologia) and photographed using a digital camera with the aid of the L-Pix program (Loccus). The concentration of DNA in each sample was measured with a spectrophotometer (NanoDrop).

Design of Primers and Amplification of Target Regions

A pair of specific primers was designed for detecting the 12-bp indel (prnpBovin12F: 5'-GGTCAGCGTAAATAGAGTCCTT-3'; prnpBovin12R: 5'-TCGCCCTTGTTC TGATTCGC-3'), amplifying a sequence of $400 \mathrm{bp}$, and another pair was designed for detecting the 23-bp indel (prnpBovin23F: 5'-TCTTCCTGGGACAGCTTCT TAGTACAG-3'; prnpBovin23R: 5'-AAGGCATTCATATAGGTGAGGGTTTG AG- $3^{\prime}$ ), amplifying a sequence of $393 \mathrm{bp}$. These primers were designed by accessing the AJ298878 bovine PRNP gene deposited in GenBank and using the Oligo program.

The target regions of the $P R N P$ gene were amplified by polymerase chain reaction (PCR) using 40-60 ng DNA per 22- $\mu$ l reaction volume containing $10 \times$ buffer, $1.5 \mathrm{mM} \mathrm{MgCl} 2,0.5 \mathrm{mM}$ dNTPs, 5 pmol of each primer, and $1 \mathrm{U}$ Taq DNA polymerase (CenBiot), and the specific primers mentioned above. The amplification consisted of initial denaturation at $94{ }^{\circ} \mathrm{C}$ for $5 \mathrm{~min}$, followed by 34 cycles of $94{ }^{\circ} \mathrm{C}$ for $45 \mathrm{~s}, 58{ }^{\circ} \mathrm{C}$ (indel 12) and $60{ }^{\circ} \mathrm{C}$ (indel 23) for $45 \mathrm{~s}$, and $72{ }^{\circ} \mathrm{C}$ for $2 \mathrm{~min}$, with a final extension at $72{ }^{\circ} \mathrm{C}$ for $5 \mathrm{~min}$.

Genotyping

PCR products underwent electrophoresis on $3 \%$ agarose gel (Promega). The $1 \mathrm{~Kb}$ Plus DNA Ladder (Invitrogen) was used to determine the heights of the bands formed, which were viewed with an ultraviolet light transilluminator (Loccus) and photographed using a digital camera and the L-Pix program. Based on the gel 
analysis, animals with only the 12-bp indel or the 23-bp indel were designated homozygous, whereas heterozygous animals were those with both the 12-bp indel and the 23-bp indel. The haplotypes and diplotypes of each animal were then determined.

\section{Statistical Analysis}

Genotype and allele frequencies were calculated and Hardy-Weinberg equilibrium tested to determine whether the allele frequencies remained constant over generations. Haplotype and diplotype frequencies were determined. The linkage disequilibrium test (Lewontin 1988) was used to analyze the degree of dependence between haplotypes. Of the 40 animals sampled, 15 were double heterozygotes; we estimated their diplotype numbers using conditional probability $(P)$ and haplotype frequencies, as follows:

$$
\begin{aligned}
& P(12 \text { ins }-23 \text { del })=5 / 50 \\
& P(12 \text { del }-23 \text { ins })=7 / 50 \\
& P(12 \text { del }-23 \text { del })=2 / 50 \\
& P(12 \text { ins }-23 \text { ins })=36 / 50
\end{aligned}
$$

From the haplotype frequencies, diplotype values were estimated for the 15 animals with the double heterozygous genotype as follows:

$$
\begin{aligned}
& P(12 \text { ins }-23 \text { ins } / 12 \text { del }-23 \mathrm{del}) \\
& =\frac{[P(12 \text { ins }-23 \text { ins }) \times P(12 \text { del }-23 \mathrm{del})] \times 2}{[P(12 \text { ins }-23 \mathrm{del}) \times P(12 \mathrm{del}-23 \mathrm{del}) \times 2]+[P(12 \text { ins }-23 \mathrm{del}) \times P(12 \mathrm{del}-23 \text { ins }) \times 2]}
\end{aligned}
$$

The correlation test was used to determine the degree of mutual relationship between the two polymorphic regions that formed haplotypes. All calculations were performed in silico with the aid of spreadsheet formulas.

\section{Sequencing}

The PCR products of some samples were purified using the Qiaex II kit (Qiagen). With purified samples, the sequencing reaction was performed with the BigDye Terminator v3.1 kit (Applied Biosystems), using $1 \mu \mathrm{l}$ forward primer and $1 \mu \mathrm{l}$ reverse primer ( 5 pmol) in separate reactions, $2 \mu$ l BigDye, $2 \mu \mathrm{l} 5 \times$ buffer, and $5 \mu \mathrm{l}$ purified PCR. The plate with the reactions was placed in a thermocycler, purified with EDTA and ethanol, and resuspended in formamide. For analysis of the positions of 12-bp and 23-bp indels, the samples were sequenced using the Sanger (2004) procedure in a capillary sequencer (Applied Biosystems model 3130). The sequencing results were analyzed and aligned with accession AJ298878 using the BLASTn program of the National Center for Biotechnology Information. The quality of the waves in the electropherogram was analyzed with the BioEdit program to determine whether the regions were polymorphic in exact locations, as described for other breeds. 


\section{Results}

From the gel electrophoresis, the amplification pattern of polymorphic regions for heterozygous and homozygous animals was identified based on the specific primers (Fig. 1). The conformation of the bands applies to both indels (12 and $23 \mathrm{bp}$ ). Heterozygous animals exhibited the ins/del genotype (one allele with the insertion and the other with the deletion); homozygous animals exhibited either the del/del genotype (deletion in both alleles) or the ins/ins genotype (insertion in both alleles).

In the sequence of each polymorphic region, the online BLASTn and BioEdit programs clearly identified the expected genotype profiles in accordance with the gel analysis: insertion, deletion, and heterozygous polymorphisms of $12 \mathrm{bp}$ in intron 1 (Fig. 2) and insertion, deletion, and heterozygous polymorphisms of $23 \mathrm{bp}$ in the promoter region (Fig. 3). For heterozygous animals, when the BioEdit program was used, nucleotides appeared from or near the region of polymorphism that are not part of the sequence of the bovine PRNP gene. When BLASTn was used, the alignment of the sequence from the heterozygous animals stopped at or near the region of polymorphism, and the nucleotides that appeared in the electropherogram after the region of interest were not recognized. This was characteristic in these samples.

For the two polymorphic regions, values were calculated for the degree of inbreeding and kinship of each individual with respect to the remaining animals in the group studied. The animals (numbered 1-40) were divided into groups based on the formation of genotypes, which could also determine their haplotypes and diplotypes (Table 1). Haplotype and diplotype frequencies were estimated for the two indels in the 15 animals that were doubly heterozygous (specimens with the 12ins/del and 23ins/del genotypes), as animals with such profiles generated four haplotypes and two diplotypes. This estimation was necessary before adding their data to those of the other animals and performing further calculations.

Expected genotype and allele frequencies were calculated for the polymorphisms of the two indels among the 40 animals (Table 2), and the frequencies of the haplotype profiles of the two indels in the same chromosome were also calculated (Table 3). An analysis of the polymorphisms in the chromosome pairs of the cattle yielded diplotype frequencies (Table 4 ). The conditional probability $(P)$ of the 15 doubly heterozygous animals was estimated to be $P(12$ ins-23del $)=0.10$, $P(12$ del-23ins $)=0.14, P(12$ del-23del $)=0.04$, and $P(12$ ins -23 ins $)=0.72$.

For the diplotype $12 \mathrm{ins}-23 \mathrm{ins} / 12 \mathrm{del}-23 \mathrm{del}, P$ was 0.67 , equivalent to 10 of the 15 doubly heterozygous animals. This allowed us to calculate $P$ (12ins-23del/

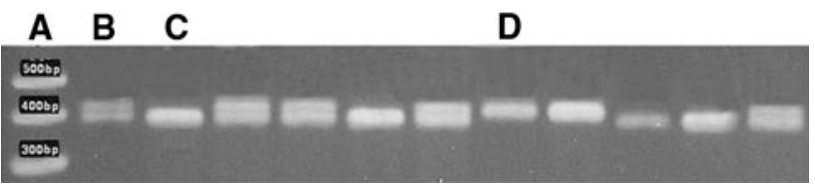

Fig. 1 Electrophoretic profile of the PRNP gene in Caracu cattle. Lanes $A$ base pair pattern; $B$ band characteristic of heterozygous animals; $C$ band characteristic of homozygous animals with deletion; $D$ band characteristic of homozygous animals with insertion 

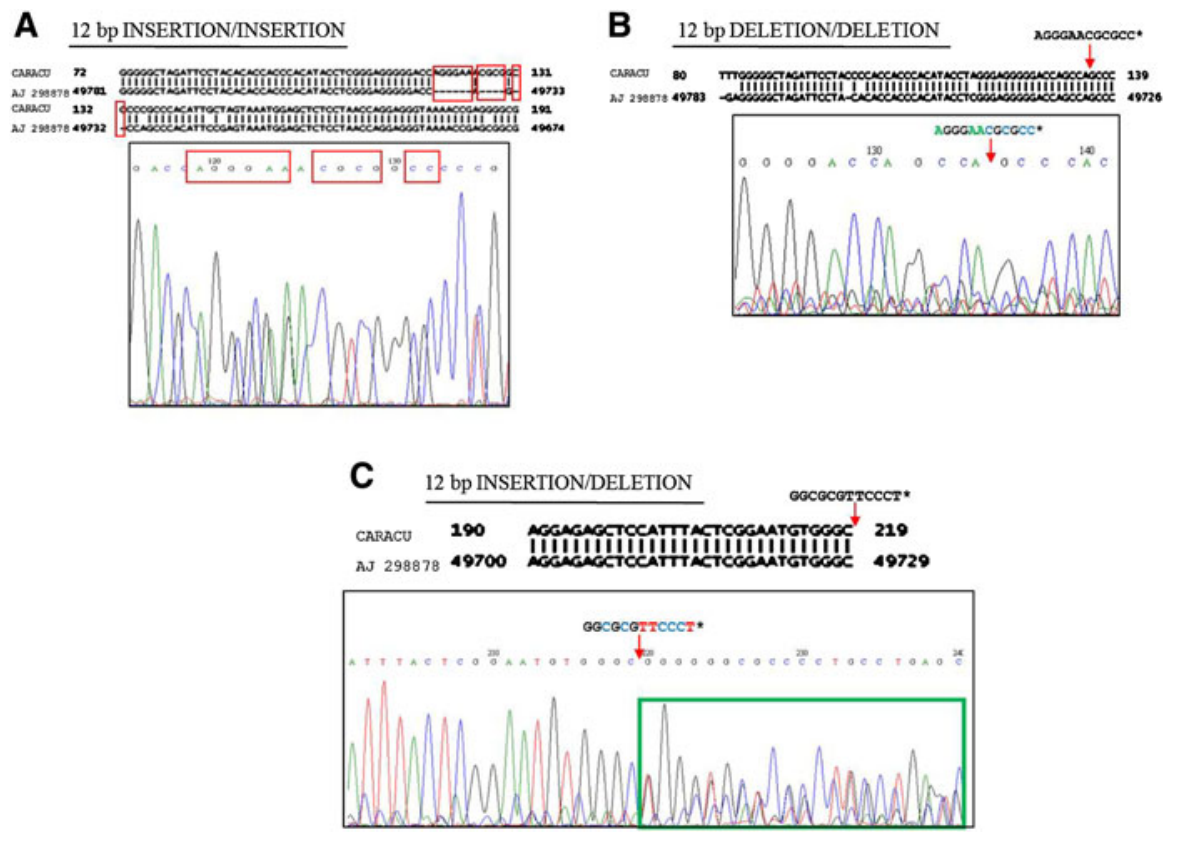

Fig. 2 Comparison of 12-bp polymorphisms in a specific region of the PRNP gene in Caracu cattle. BLASTn alignments of sequences from Caracu animals and the bovine PRNP gene AJ298878, deposited in GenBank, appear above an electropherogram of the same region of the Caracu gene. A Homozygous Caracu, with 12-bp insertion (in both alleles) boxed; sequence obtained from reverse direction $\left(3^{\prime}-5^{\prime}\right)$. B Homozygous Caracu, with arrow indicating position (in both alleles) where 12-bp sequence (asterisk) is deleted; asterisk sequence obtained from reverse direction $\left(3^{\prime}-5^{\prime}\right)$. C Heterozygous Caracu, with arrow indicating position of 12-bp insertion (asterisk) in one allele and deletion in the other; overlap and differences in wave characteristics are boxed; asterisk sequence obtained from forward direction $\left(5^{\prime}-3^{\prime}\right)$ (color figure online)

12 del-23ins) as $1.00-0.67$, or 0.33 , which equates to 5 of 15 heterozygous animals. Following the principle of chromosome distribution $(n+n=2 n)$, we estimated the number of haplotypes that originated from the diplotypes of these 15 animals (Table 3).

\section{Discussion}

The insertion and/or deletion of $12 \mathrm{bp}$ in intron 1 and $23 \mathrm{bp}$ in the promoter region of the bovine PRNP gene is one of the most studied polymorphisms used to determine a possible genetic predisposition toward developing BSE. Previous studies have compared these polymorphisms in healthy cattle with those in BSEinfected cattle, and it is now possible to distinguish polymorphisms that may be associated with the traits of resistance and susceptibility to BSE (Sander et al. 2004).

Electrophoresis of the amplification of target regions in $3 \%$ agarose gel is an important tool for detecting resistant genotypes. In the present study, homozygous genotypes resistant to BSE (ins/ins), homozygous genotypes susceptible to BSE 
A $23 \mathrm{bp} \mathrm{INSERTION/INSERTION}$

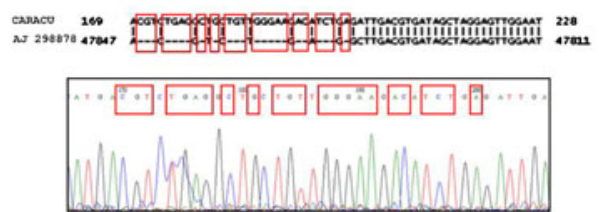

B

23 bP DELETION/DELETION

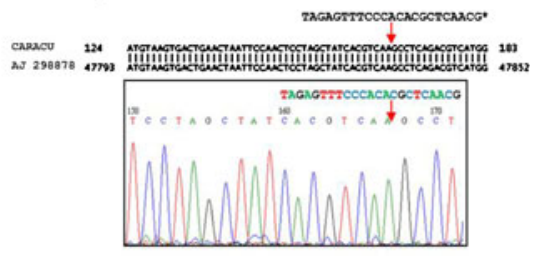

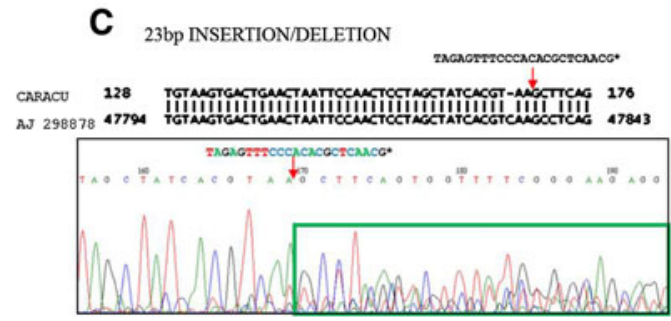

Fig. 3 Comparison of 23-bp polymorphisms in a specific region of the PRNP gene in Caracu cattle. BLASTn alignments of sequences from Caracu animals and the bovine PRNP gene AJ298878, deposited in GenBank, appear above an electropherogram of the same region of the Caracu gene. A Homozygous Caracu, with 23-bp insertion (in both alleles) boxed; sequence obtained from reverse direction $\left(3^{\prime}-5^{\prime}\right)$. B Homozygous Caracu, with arrow indicating position (in both alleles) where 23-bp sequence (asterisk) is deleted; asterisk sequence obtained from forward direction $\left(5^{\prime}-3^{\prime}\right)$. C Heterozygous Caracu, with arrow indicating position of 23-bp insertion (asterisk) in one allele and deletion in the other; overlap and differences in wave characteristics are boxed; asterisk sequence obtained from forward direction $\left(5^{\prime}-3^{\prime}\right)$ (color figure online)

(del/del), and heterozygous genotypes (ins/del) were identified from the differing heights of the bands formed by 12- and 23-bp insertions and deletions (Fig. 1). Recent studies have reported the results of electrophoresis used to identify these genotypes in German and Japanese cattle (Sander et al. 2004; Nakamitsu et al. 2006), which served as a basis for our analysis of polymorphisms in Caracu cattle.

The sequencing was used as an auxiliary tool for viewing the polymorphisms and confirming both the electrophoretic results and the alignment of the polymorphisms with those of accession AJ298878 (Sander et al. 2004). The BLASTn results allowed visualization of the polymorphisms, especially the insertion of base pairs in the two alleles (Figs. 2, 3). The heterozygous profile for both the 12- and 23-bp sequences merits attention. One allele of the heterozygote has the insertion, and the other has the deletion. Thus, two bands are formed in the agarose gel, one corresponding to the amplified fragment with the insertion and the other corresponding to the amplified fragment with the deletion (Fig. 1). An analysis of the specific polymorphic region in the electropherogram reveals overlapping waves formed by nucleotides and a subsequent disorder of nucleotides and their respective waves due to the alleles having different numbers of nucleotides in the region amplified by the PCR (Figs. 2, 3).

The genotype and allele frequencies were based on the electrophoretic results (Table 2) and were compared with those of previous studies of other cattle breeds (Table 5). Despite differences in the number of samples between studies, the 
Table 1 Kinship of 40 Caracu cattle genotyped for two PRNP polymorphisms

\begin{tabular}{|c|c|c|c|c|c|c|}
\hline \multirow{2}{*}{$\begin{array}{l}\text { Animal } \\
\text { ID no. }\end{array}$} & \multirow[t]{2}{*}{$F_{i}(\%)^{\mathrm{a}}$} & \multirow{2}{*}{$\begin{array}{l}\text { Kinship } \\
(\%)^{\mathrm{b}}\end{array}$} & \multicolumn{2}{|c|}{ Genotype } & \multirow{2}{*}{$\begin{array}{l}\text { Haplotype } \\
12-23\end{array}$} & \multirow{2}{*}{$\begin{array}{l}\text { Diplotype } \\
12-23 / 12-23\end{array}$} \\
\hline & & & $12 / 12$ & $23 / 23$ & & \\
\hline 8 & 0 & 1.4 & Del/del & Del/del & $\begin{array}{l}\text { 12del-23del } \\
12 \mathrm{del}-23 \mathrm{del}\end{array}$ & 12del-23del/12del-23del \\
\hline 1 & 0.29 & 7.03 & Ins/ins & Ins/del & $12 \mathrm{ins}-23 \mathrm{ins}$ & 12 ins-23ins/12ins-23del \\
\hline 6 & 2.84 & 7.03 & & & 12 ins-23del & \\
\hline 12 & 1.21 & 2.15 & & & & \\
\hline 15 & 0 & 5.29 & & & & \\
\hline 29 & 0 & 1.35 & & & & \\
\hline 3 & 2.39 & 5.29 & Ins/ins & Ins/ins & 12ins-23ins & 12ins-23ins/12ins-23ins \\
\hline 7 & 0.78 & 3.22 & & & 12ins-23ins & \\
\hline 11 & 2.99 & 4.86 & & & & \\
\hline 20 & 4.33 & 5.09 & & & & \\
\hline 21 & 4.75 & 3.19 & & & & \\
\hline 22 & 0 & 2.51 & & & & \\
\hline 23 & 0 & 0 & & & & \\
\hline 24 & 0.90 & 2.87 & & & & \\
\hline 25 & 0.04 & 3.83 & & & & \\
\hline 26 & 0 & 3.28 & & & & \\
\hline 27 & 0 & 0 & & & & \\
\hline 32 & 0.99 & 5.85 & & & & \\
\hline 37 & 0 & 1.74 & & & & \\
\hline 39 & 3.98 & 4.20 & & & & \\
\hline 40 & 2.83 & 3.98 & & & & \\
\hline 28 & 1.66 & 3.54 & Del/del & Ins/ins & $12 \mathrm{del}-23 \mathrm{ins}$ & $12 \mathrm{del}-23 \mathrm{ins} / 12 \mathrm{del}-23 \mathrm{ins}$ \\
\hline 30 & 0.53 & 3.93 & & & 12del-23ins & \\
\hline 31 & 0.94 & 2.90 & & & & \\
\hline 35 & 4 & 4.39 & Ins/del & Ins/ins & $\begin{array}{l}\text { 12ins-23ins } \\
12 \text { del-23ins }\end{array}$ & $12 \mathrm{ins}-23 \mathrm{ins} / 12 \mathrm{del}-23 \mathrm{ins}$ \\
\hline 2 & $\mathbf{0}$ & $\mathbf{0}$ & Ins/del & Ins/del & 12ins-23ins & 12ins-23ins/12del-23del \\
\hline 4 & $\mathbf{0}$ & $\mathbf{0}$ & & & 12del-23del & 12ins-23del/12del-23ins \\
\hline 5 & $\mathbf{0}$ & 3.49 & & & 12ins-23del & \\
\hline 9 & $\mathbf{0}$ & 1.28 & & & 12del-23ins & \\
\hline 10 & 9.02 & 5.68 & & & & \\
\hline 13 & 0 & 1.28 & & & & \\
\hline 14 & 2.15 & 4.45 & & & & \\
\hline 16 & 0 & 0.66 & & & & \\
\hline 17 & 0.96 & 5.10 & & & & \\
\hline 18 & 1.90 & 2.44 & & & & \\
\hline 19 & 0 & 1.06 & & & & \\
\hline 33 & 0 & 1.51 & & & & \\
\hline
\end{tabular}


Table 1 continued

\begin{tabular}{|c|c|c|c|c|c|c|}
\hline \multirow{2}{*}{$\begin{array}{l}\text { Animal } \\
\text { ID no. }\end{array}$} & \multirow[t]{2}{*}{$F_{i}(\%)^{\mathrm{a}}$} & \multirow{2}{*}{$\begin{array}{l}\text { Kinship } \\
(\%)^{\mathrm{b}}\end{array}$} & \multicolumn{2}{|c|}{ Genotype } & \multirow{2}{*}{$\begin{array}{l}\text { Haplotype } \\
12-23\end{array}$} & \multirow{2}{*}{$\begin{array}{l}\text { Diplotype } \\
12-23 / 12-23\end{array}$} \\
\hline & & & $12 / 12$ & $23 / 23$ & & \\
\hline 34 & 1.61 & 5.71 & & & & \\
\hline 36 & 2.25 & 3.40 & & & & \\
\hline 38 & 0.01 & 5.96 & & & & \\
\hline
\end{tabular}

${ }^{a}$ Degree of consanguinity (inbreeding); mean $F_{i}=1.33 \%$

${ }^{\mathrm{b}}$ Mean kinship $=3.27 \%$

Bold type indicates data for the 15 animals that were doubly heterozygous (number of haplotypes and estimated diplotypes were used in calculations of frequencies, Hardy-Weinberg, linkage disequilibrium, and correlation)

majority of breeds exhibit a high frequency of $12 \mathrm{del}$ and $23 \mathrm{del}$ alleles (Kerber et al. 2008). The breed with the highest frequency is the Japanese Holstein, at $74 \%$ for $12 \mathrm{del}$ and $79 \%$ for $23 \mathrm{del}$ (Nakamitsu et al. 2006). The Polish Holstein-Friesian exhibits frequencies of $54 \%$ for $12 \mathrm{del}$ and $63 \%$ for $23 \mathrm{del}$ (Czarnik et al. 2007).

In the present study, the Caracu breed exhibited a high frequency of 12ins (70 \%) and 23ins $(72.5 \%)$ alleles. Compared with zebu breeds (Bos indicus), taurines (B. taurus) have a greater percentage of alleles for susceptibility, especially in the promoter region (23del) (Brunelle et al. 2008). The Hardy-Weinberg test revealed that the animals of the present study were in equilibrium at both regions $(P>0.05)$, indicating that there was no selection, mutation, and/or migration that could affect their frequencies over generations.

There are hypotheses that these and other polymorphisms in the bovine PRNP gene have an Indian origin. Zebu breeds, which contributed to the improvement of European breeds (Bos taurus), could have passed down deletion alleles (Richt and Hall 2008). One study found 10 polymorphisms in a single nucleotide in the exon 3 region of the PRNP gene in Caracu cattle; one of them encodes a change in the expression of an amino acid, and nine were determined to be silent mutations that could be related to BSE resistance and susceptibility (Kues et al. 2006).

The haplotypes described in the present study indicate that the 12-bp and 23-bp indels occur together in a single allele (Table 1). It is therefore possible to obtain an overview of how many alleles, or chromosomes, are associated with the two polymorphisms. The specimens of Caracu cattle exhibited 46 chromosomes $(57.5 \%)$ with 12 ins-23ins, which is a high frequency in the group of 40 animals examined (Table 3). This chromosome with two insertions is important in that it can segregate in future generations.

The 12ins-23ins haplotype has been reported with a frequency of $46 \%$ in healthy Swiss cattle and $37 \%$ in those infected with BSE (Haase et al. 2007); lower frequencies have been reported for healthy specimens of Aberdeen Angus (25\%), Charolais (31\%), and Franqueiro (36\%) (Kerber et al. 2008). The frequency of the resistant haplotype is reported to be $24 \%$ in the UK Holstein, $30 \%$ in the German Holstein, $45 \%$ in the German Brown, and $27 \%$ in the Fleckvieh (Juling et al. 
Table 2 Genotype and allele frequencies for PRNP indels in 40 Caracu cattle

\begin{tabular}{lllllll}
\hline PRNP indel & \multicolumn{2}{l}{ Genotype (\%) } & & \multicolumn{2}{l}{ Allele (\%) } \\
\cline { 2 - 5 } & Ins/ins & Del/del & Ins/del & & Ins & Del \\
\hline 12 bp (400-412 bp) & 50 & 10 & 40 & 70 & 30 \\
23 bp (393-416 bp) & 47.5 & 2.5 & 50 & 72.5 & 27.5 \\
\hline
\end{tabular}

Hardy-Weinberg test, 12-bp indel $\left(\chi^{2}=0.09\right), P>0.05 ; 23$-bp indel $\left(\chi^{2}=2.58\right), P>0.05$

Table 3 Haplotype frequency in Caracu cattle

\begin{tabular}{lccll}
\hline Haplotype & \multicolumn{2}{l}{ Number of chromosomes $(n)$} & Frequency $(\%)$ \\
\cline { 2 - 5 } & $n$ & Doubly heterozygous $n^{\mathrm{a}}$ & Total $^{\mathrm{b}}$ & \\
\hline 12ins-23del & 5 & 5 & 10 & 12.5 \\
12 del-23ins & 7 & 5 & 12 & 15 \\
12 del-23del & 2 & 10 & 12 & 15 \\
12 ins-23ins & 36 & 10 & 46 & 57.5 \\
\hline
\end{tabular}

${ }^{a}$ Estimated from 15 doubly heterozygous animals (bold type in Table 4)

${ }^{\mathrm{b}}$ Used for calculating frequencies; linkage disequilibrium test, $D=0.0675$ and $D^{\prime}=0.3506$; correlation test, $r=0.33$

Table 4 Diplotype frequency in Caracu cattle

\begin{tabular}{lcc}
\hline Diplotype & Number of animals & Frequency $(\%)$ \\
\hline 12del-23del/12del-23del & 1 & 2.5 \\
12ins-23ins/12del-23ins & 1 & 2.5 \\
12ins-23del/12del-23ins & $\mathbf{1}$ & $\mathbf{2 . 5}$ \\
12del-23ins/12del-23ins & 3 & 7.5 \\
12ins-23ins/12ins-23del & 5 & 12.5 \\
12ins-23ins/12del-23del & $\mathbf{1 4}$ & $\mathbf{3 5}$ \\
12ins-23ins/12ins-23ins & 15 & 37.5
\end{tabular}

Bold type indicates data for the 15 doubly heterozygous animals (bold type in Table 1)

2006). In the Polish Holstein-Friesian, the haplotype was present at a frequency of $36.3 \%$ (Czarnik et al. 2011).

The haplotypes calculated from 40 animals in the present study showed a linkage disequilibrium of $35.06 \%\left(D^{\prime}=0.3506\right)$. This disequilibrium is fairly low in comparison with the values for the Aberdeen Angus (87\%), Charolais (95\%), and Franqueira (99\%) breeds (Kerber et al. 2008). In the Caracu breed, these haplotypes have a certain dependence, and the loci that form the different haplotypes tend toward a medium degree of correlation $(r=0.33)$.

Polymorphisms in the chromosome pair were analyzed in the diplotypes (Table 1). Of the 40 animals, 15 (37.5\%) were found to exhibit the 12ins-23ins/ 12ins-23ins diplotype (Table 4). Lower frequencies of this diplotype have been 
Table 5 Allele frequencies for the 12- and 23-bp PRNP indels reported in various cattle breeds

\begin{tabular}{|c|c|c|c|c|c|}
\hline \multirow[t]{3}{*}{ Breed (reference) } & \multirow[t]{3}{*}{ Sample size } & \multicolumn{4}{|c|}{ Allele } \\
\hline & & \multicolumn{2}{|c|}{12 bp } & \multicolumn{2}{|c|}{$23 \mathrm{bp}$} \\
\hline & & Ins & Del & Ins & Del \\
\hline German (Sander et al. 2004) & 48 & 49 & 51 & 43 & 57 \\
\hline US beef (Clawson et al. 2006) & 96 & 37 & 63 & 26 & 74 \\
\hline US dairy (Clawson et al. 2006) & 96 & 53 & 47 & 38 & 62 \\
\hline German Holstein (Juling et al. 2006) & 127 & 47 & 53 & 38 & 62 \\
\hline German Brown (Juling et al. 2006) & 43 & 86 & 14 & 65 & 35 \\
\hline Fleckvieh (Juling et al. 2006) & 106 & 38 & 62 & 32 & 68 \\
\hline Japanese Holstein (Nakamitsu et al. 2006) & 278 & 26 & 74 & 21 & 79 \\
\hline Japanese Brown (Nakamitsu et al. 2006) & 186 & 43 & 57 & 41 & 59 \\
\hline Polish Holstein-Friesian (Czarnik et al. 2007) & 234 & 46 & 54 & 37 & 63 \\
\hline Swiss (Haase et al. 2007) & 294 & 54 & 46 & 46 & 54 \\
\hline German Holstein (Kashkevich et al. 2007) & 17 & 47 & 53 & 42 & 58 \\
\hline Braunvieh (Kashkevich et al. 2007) & 17 & 84 & 16 & 60 & 40 \\
\hline Fleckvieh (Kashkevich et al. 2007) & 44 & 36 & 64 & 29 & 71 \\
\hline Zebu (Bos indicus) (Brunelle et al. 2008) & 116 & 87 & 13 & 12 & 88 \\
\hline Bos indicus $\times$ B. taurus (Brunelle et al. 2008) & 76 & 47 & 53 & 20 & 80 \\
\hline Taurine (Bos taurus) (Brunelle et al. 2008) & 4,552 & 45 & 55 & 38 & 62 \\
\hline Aberdeen Angus (Kerber et al. 2008) & 99 & 44 & 56 & 27 & 73 \\
\hline Charolais (Kerber et al. 2008) & 82 & 42 & 58 & 22 & 68 \\
\hline Franqueiro (Kerber et al. 2008) & 73 & 67 & 33 & 36 & 64 \\
\hline Vietnamese dairy (Muramatsu et al. 2008) & 206 & 52 & 48 & 15 & 85 \\
\hline Korean (Kim et al. 2009) & 437 & 44 & 56 & 44 & 56 \\
\hline Polish Holstein-Friesian (Czarnik et al. 2011) & 837 & 47.3 & 52.7 & 37.8 & 62.2 \\
\hline Caracu (this study) & 40 & 70 & 30 & 72.5 & 27.5 \\
\hline
\end{tabular}

reported for Aberdeen Angus (3\%), Charolais (10\%), and Franqueiro (16\%) breeds (Kerber et al. 2008). Juling et al. (2006) reported frequencies in healthy specimens of other breeds, including UK Holstein (3\%), German Holstein (15\%), German Brown (46\%), and Fleckvieh (11\%).

There have been no cases of BSE in Brazil, and therefore we made no comparisons with affected animals. Our aim was to gather information on the degree of inbreeding and kinship among Caracu cattle from 40 breeders, because data on polymorphisms of the bovine PRNP gene are useful to genetic improvement programs. Breeders are an integral part of an important Brazilian genetic improvement program aimed at the productive development of the Caracu breed. Caracu cattle are of European origin and, after more than 400 years of establishment in Brazil, are fully adapted to the country's various environments. Over all that time, 12 ins and 23ins alleles have been passed from generation to generation, down to the cattle analyzed in the present study. As demonstrated by the Hardy-Weinberg test, 
the loci are in equilibrium; that is, these regions have not undergone significant changes that would affect their allele frequencies over generations.

The BSE cases recorded so far merit attention. Most cases of the disease in the countries where the precursor breeds of the Caracu originated (Portugal and Spain) have been traced to the importation of animals infected with the prion (OIE 2007). There are no reports of this disease in Caracu cattle.

Thus, based on our analysis of the PRNP gene in the present study, the cattle raised by these Caracu breeders have a genotypic profile similar to that of healthy cattle from other studies and significantly different from that of BSE-affected cattle. The search for indel and other polymorphisms of the bovine PRNP gene is important for eventually forming a screening program of cattle resistant to BSE, in order to control and reduce cases of this disease worldwide. From there, breeding would be a new tool to combat BSE, contributing to public health and lessening the economic impact of the disease.

Acknowledgments The authors are grateful to Embrapa Gado de Corte and GenePlus for providing laboratories and samples; the Brazilian fostering agencies Fundação de Apoio ao Desenvolvimento do Ensino, Ciência e Tecnologia do Estado de Mato Grosso do Sul (FUNDECT), Conselho Nacional de Desenvolvimento Científico e Tecnológico (CNPq), and Financiadora de Estudo e Projetos (FINEP) for fellowships and funding for the project; and the master's program in Animal Science of the Universidade Federal de Mato Grosso do Sul (UFMS).

\section{References}

ABCC (2009) Programa de melhoramento da raça Caracu, Geneplus-Embrapa, IAPAR. http://www.cnpgc.embrapa.br/ locs/sumario/caracu/car_index.htm. Accessed 30 Mar 2010

Brunelle BW, Greenlee JJ, Seabury CM, Brown CE, Nicholson EM (2008) Frequencies of polymorphisms associated with BSE resistance differ significantly between Bos taurus, Bos indicus, and composite cattle. BMC Vet Res 4:36

Clawson ML, Heaton MP, Keele JW, Smith TP, Harhay GP, Laegreid WW (2006) Prion gene haplotypes of U.S. cattle. BMC Genet 7:51

Criar e Plantar (2008) Caracu. http://www.criareplantar.com.br. Accessed 30 Mar 2010

Czarnik U, Zabolewicz T, Strychalski J, Grzybowski G, Bogusz M, Walawski K (2007) Deletion/ insertion polymorphism of the prion protein gene $(P R N P)$ in Polish Holstein-Friesian cattle. $\mathrm{J}$ Appl Genet 48:69-71

Czarnik U, Strychalski J, Zabolewicz T, Pareek CS (2011) Populationwide investigation of two indel polymorphisms at the prion protein gene in Polish Holstein-Friesian cattle. Biochem Genet 49:303-312

Haase B, Doherr MG, Seuberlich T, Drogemuller C, Dolf G, Nicken P, Schiebel K, Ziegler U, Groschup MH, Zurbriggen A, Leeb T (2007) PRNP promoter polymorphisms are associated with BSE susceptibility in Swiss and German cattle. BMC Genet 8:15

Juling K, Schwarzenbacher H, Williams JL, Fries R (2006) A major genetic component of BSE susceptibility. BMC Biol 4:33

Kashkevich K, Humeny A, Ziegler U, Groschup MH, Nicken P, Leeb T, Fischer C, Becker CM, Schiebel K (2007) Functional relevance of DNA polymorphisms within the promoter region of the prion protein gene and their association to BSE infection. FASEB J 21:1547-1555

Kerber AR, Hepp D, Passos DT, de Azevedo Weimer T (2008) Polymorphisms of two indels at the PRNP gene in three beef cattle herds. Biochem Genet 46:1-7

Kim Y, Kim JB, Sohn H, Lee C (2009) A national survey on the allelic, genotypic, and haplotypic distribution of PRNP insertion and deletion polymorphisms in Korean cattle. J Genet 88:99-103 
Kues WA, Ollhoff RD, Carnwath JW, de Souza FP, Madeira HM, Niemann H (2006) High incidence of single nucleotide polymorphisms in the prion protein gene of native Brazilian Caracu cattle. J Anim Breed Genet 123:326-330

Lewontin RC (1988) On measures of gametic disequilibrium. Genetics 120:849-852

Moser M, Colello RJ, Pott U, Oesch B (1995) Developmental expression of the prion protein gene in glial cells. Neuron 14:509-517

Muramatsu Y, Sakemi Y, Horiuchi M, Ogawa T, Suzuki K, Kanameda M, Hanh TT, Tamura Y (2008) Frequencies of $P R N P$ gene polymorphisms in Vietnamese dairy cattle for potential association with BSE. Zoonoses Public Health 55:267-273

Nakamitsu S, Miyazawa T, Horiuchi M, Onoe S, Ohoba Y, Kitagawa H, Ishiguro N (2006) Sequence variation of bovine prion protein gene in Japanese cattle (Holstein and Japanese Black). J Vet Med Sci 68:27-33

OIE (2007) Geographical distribution of countries that reported confirmed cases of BSE since 1989. World Organisation for Animal Health. http://www.oie.int/eng/info/en_statesb.htm. Accessed 25 Oct 2009

Prusiner SB (1982) Novel proteinaceous infectious particles cause scrapie. Science 216:136-144

Prusiner SB, Scott MR (1997) Genetics of prions. Annu Rev Genet 31:139-175

Regitano LCA, Coutinho LL (2001) Biologia molecular aplicada à produção animal. Embrapa Inf. Tec, Brasília

Richt JA, Hall SM (2008) BSE case associated with prion protein gene mutation. PLoS Pathog 4:e1000156

Sander P, Hamann H, Pfeiffer I, Wemheuer W, Brenig B, Groschup MH, Ziegler U, Distl O, Leeb T (2004) Analysis of sequence variability of the bovine prion protein gene $(P R N P)$ in German cattle breeds. Neurogenetics 5:19-25

Sander P, Hamann H, Drogemuller C, Kashkevich K, Schiebel K, Leeb T (2005) Bovine prion protein gene $(P R N P)$ promoter polymorphisms modulate PRNP expression and may be responsible for differences in bovine spongiform encephalopathy susceptibility. J Biol Chem 280:37408-37414

Sanger F (2004) Determination of nucleotide sequences in DNA. Biosci Rep 24:237-253

Schläpfer J, Stahlberger-Saitbekova N, Küffer J, Dolf G (2000) Genetic mapping of the prion protein gene (PRNP) on bovine chromosome 13. J Anim Breed Genet 117:211-216

Wilesmith JW, Wells GA, Cranwell MP, Ryan JB (1988) Bovine spongiform encephalopathy: epidemiological studies. Vet Rec 123:638-644

Zadworny D, Kuhnlein U (1990) The identification of the kappa-casein genotype in Holstein dairy cattle using the polymerase chain reaction. Theor Appl Genet 80:631-634 